\title{
ANALISIS IMPLEMENTASI JUAL BELI SISTEM PRE ORDER MENURUT FATWA DSN NO 05/DSN-MUI/IV/2000 TENTANG JUAL BELI SALAM \\ (Studi Kasus Pada Pengrajin Batik Asad Kertijayan Pekalongan)
}

\author{
Nur Apriyanti ${ }^{1}$, Sobrotul Imtikhanah ${ }^{2}$, Moegiri ${ }^{3}$ \\ 1,3Program Studi S1 Ekonomi Syariah Fakultas Ekonomika dan Bisnis Universitas \\ Muhammadiyah Pekajangan Pekalongan \\ 2Program Studi S1 Akuntansi Fakultas Ekonomika dan Bisnis Universitas \\ Muhammadiyah Pekajangan Pekalongan \\ E mail : moebandeng@gmail.com
}

\begin{abstract}
Abstrak
Penelitian ini bertujuan untuk untuk mengetahui kesesuaian penerapan sistem jual beli pre order (Salam) yang dilakukan oleh pengusaha atau produsen batik Asad Kertijayan Pekalongan dengan Fatwa DSN NO 05/DSN-MUI/IV/2000 Tentang Jual Beli Salam. Penelitian ini merupakan penelitian kualitatif dengan metode pengumpulan data dengan teknik observasi dan teknik wawancara dan penentuan informan atau sumber data yang dilakukan secara snowballing. Berdasarkan hasil penelitian, tentang pelaksanaan jual beli sistem pre order (Salam) pada batik Asad Kertijayan Pekalongan, dari beberapa ketentuan-ketentuan yang ada pada Fatwa DSN NO 05/DSN-MUI/IV/2000 Tentang Jual Beli Salam yaitu ketentuan tentang pembayaran, ketentuan tentang barang, ketentuan tentang penyerahan barang, dan ketentuan tentang rukun dan syarat jual beli Salam dalam Islam. Pelaksanaan sistem jual beli pre order telah sesuai dengan Fatwa DSN NO 05/DSN-MUI/IV/2000 Tentang Jual Beli Salam. Pelaksanaan sistem jual beli pre order pada batik Asad Kertijayan Pekalongan yaitu pembeli memesan batik kepada batik Asad. Dalam sistem pembayaran pembeli membayarkan sepenuhnya jumlah uang yang telah ditentukan sebagai tanda jadi akad sesuai dengan barang yang dipesannyadan penjual akan menjelaskan tentang spesifikasi barang yang akan dipesan, jenis barang, waktu pengiriman, dan tempat penyerahannya.
\end{abstract}

Kata kunci: Salam, jual beli, ketentuan pembayaran, ketentuan barang, dan ketentuan penyerahan barang.

\section{THE ANLYSYS OF PRE-ORDER BUYING AND SELLING SYSTEM IMPLEMENTATION BASED ON FATWA DSN NO 05/DSN- MUI/IV/2000 ABOUT 'SALAM' BUYING AND SELLING SYSTEM ( A Case Study on Batik Craftsman Asad Kertijayan Pekalongan)}

\begin{abstract}
This study aims to examine the suitability of the implementation of the pre-order buying and selling system (Salam) carried out by the entrepreneur or batik producer Asad Kertijayan Pekalongan based on Fatwa DSN NO 05/DSN-MUI/IV/2000 about "Salam" buying and selling system. It is a qualitative study with an observation and interview as a data
\end{abstract}


collecting technique. The subject of this data was chosen by snowballing data. This system is customer orders batik from the Batik Asad Kertijayan Pekalongan. The buyer pays the full amount of money that has been determined as a sign of the contractin accordance with the goods ordered. Meanwhile, the seller will explain the specifications of the ordered goods, the type, the time and the place of delivery. About the implementation of pre - order buying and selling system (Salam) in Batik Asad Kertijayan Pekalonga, the provisions on payment, on goods, on delivery of goods and the provisions on the pillars and terms of sale and purchase of Salam in islam, based on Fatwa DSN NO 05/DSN-MUI/IV/2000, this system has been complied with the Fatwa.

Keywords : Salam, buying and selling, the provisions of payment, the provisions of goods, the provisions of delivery.

\section{PENDAHULUAN}

Bentuk-bentuk akad jual beli yang telah dibahas para ulama dalam fiqih muamalah terbilang sangat banyak. Salah satunya adalah jual beli dengan cara Salam, yaitu akad pemesanan suatu barang dengan kriteria yang telah disepakati dan dengan pembayaran tunai pada saat akad dilaksanakan. Dengan menggunakan akad ini, kedua belah pihak mendapatkan keuntungan tanpa ada unsur tipu menipu atau gharar.

Jual beli Salam atau pre order merupakan bentuk jual beli dengan pembayaran di muka dan penyerahan barang dikemudian hari (advanced payment atau forward buying atau future sales) dengan harga, spesifikasi, jumlah, kualitas, tanggal dan tempat penyerahan yang jelas, serta disepakati sebelumnya dalam perjanjian. Barang yang diperjual belikan belum tersedia pada saat transaksi dan harus diproduksi terlebih dahulu, seperti produkproduk pertanian dan produk-produk fungible (barang-barang yang dapat diperkirakan dan diganti sesuai berat, ukuran dan jumlahnya) lainnya. Barangbarang fungible seperti batu mulia, lukisan berharga dan lain-lain yang merupakan barang langka tidak dapat dijadikan objek Salam. Resiko terhadap barang yang diperjual belikan masih berada pada penjual sampai waktu penyerahan barang. Pihak pembeli berhak untuk meneliti dan dapat menolak barang yang akan diserahkan apabila tidak sesuai dengan spesifikasi awal yang disepakati. Qusthoniah, (2016, hlm:88).

Terkait dengan hal tersebut Dewan Syariah Nasional-Majelis Ulama Indonesia (DSN-MUI) No.05/DSN-MUI/IV/2000 tentang Jual Beli Salam memutuskan :

1.1. Ketentuan tentang Pembayaran:

1.1.1. Alat bayar harus diketahui jumlah dan bentuknya, baik berupa uang, barang, atau manfaat.

1.1.2. Pembayaran harus dilakukan pada saat kontrak disepakati.

1.1.3. Pembayaran tidak boleh dalam bentuk pembebasan hutang.

1.2. Ketentuan tentang Barang:

1.2.1. Harus jelas ciri-cirinya dan dapat diakui sebagai hutang.

1.2.2. Harus dapat dijelaskan spesifikasinya.

1.2.3. Penyerahannya dilakukan kemudian. 
1.2.4. Waktu dan tempat penyerahan barang harus ditetapkan berdasarkan kesepakatan.

1.2.5. Tidak boleh menukar barang, kecuali dengan barang sejenis sesuai kesepakatan.

1.3. Penyerahan Barang Sebelum atau pada Waktunya:

1.3.1. Penjual harus menyerahkan barang tepat pada waktunya dengan kualitas dan jumlah yang telah disepakati.

1.3.2. Jika penjual menyerahkan barang dengan kualitas yang lebih tinggi, penjual tidak boleh meminta tambahan harga.

1.3.3. Jika penjual menyerahkan barang dengan kualitas yang lebih rendah, dan pembeli rela menerimanya, maka ia tidak boleh menuntut pengurangan harga (diskon).

1.3.4. Penjual dapat menyerahkan barang lebih cepat dari waktu yang disepakati dengan syarat kualitas dan jumlah barang sesuai dengan kesepakatan, dan ia tidak boleh menuntut tambahan harga.

1.3.5. Jika semua atau sebagian barang tidak tersedia pada waktu penyerahan, atau kualitasnya lebih rendah dan pembeli tidak rela menerimanya, maka ia memiliki dua pilihan:

1.3.5.1 Membatalkan kontrak dan meminta kembali uangnya,

1.3.5.2 Menunggu sampai barang tersedia. (Dewan Syari'ah Nasional MUI No 05/DSN-MUI/IV/2000)

Tujuan penggunaan sistem jual beli pre order pada pengrajin batik Asad ini karena produk yang di produksi belum ada stoknya, sehingga pembeli atau konsumen harus memesan terlebih dahulu kepada pengrajin, setelah pembeli memesan ke pengrajin dan mentransfer biaya yang harus dibayarkan, maka batik yang telah dipesan akan diproses dan batik akan diserahkan sesuai dengan kesepakatan dari kedua belah pihak (Neni Apriliani, pemilik Batik Asad Kertijayan Pekalongan, Wawancara Pribadi, 28 Januari 2021).

Seiring dengan kemajuan zaman tidak jarang ditemukan orang yang menjual kembali barang yang masih dipesannya, namun barang tersebut belum berada di tangannya. Seperti yang terjadi pada pengrajin batik Asad Kertijayan Pekalongan. Bahwa pada usaha tersebut telah terjadi akad Salam atau pre order. Hasil wawancara dengan Bapak Reza pelanggan batik Asad dari Cirebon pada tanggal 28 Januari 2021 , Bapak Reza memesan untuk dibuatkan batik kepada Ibu Neni selaku pengrajin batik, lalu sebelum batik tersebut selesai pembuatan dan diterima oleh Bapak Reza, ternyata Bapak Reza sudah menjual atau menawarkan kembali batik tersebut kepada konsumenya. Melihat fenomena di atas bahwa telah terjadi akad Salam atau pre order pada pengrajin batik Asad Kertijayan Pekalongan antara pembeli dan pengrajin batik. Namun jika di lihat dalam putusan DSN-MUI No.05/DSN-MUI/IV/2000 tentang Jual Beli Salam, bahwa dalam ketentuan tentang barang Pembeli (mustashni') tidak boleh menjual barang sebelum menerimanya. Artiya fenomena yang terjadi di atas mengalami kesenjangan dengan fatwa yang di keluarkan oleh majelis DSNMUI. 


\section{LANDASAN TEORI}

Secara terminologi fiqh jual beli disebut dengan $a l-b a^{\prime} i$ yang berarti menjual, mengganti, dan menukar sesuatu dengan sesuatu yang lain. Lafal Al-ba'i dalam terminologi fiqh terkadang dipakai untuk pengetian lawannya, yaitu lafal alsyira' yang berarti membeli (Mardani, 2015: hlm 101). 2.1. Jual beli (al-bay')

Jual beli (al-bay')secara bahasa artinya memindahkan hak milik terhadap benda dengan akad saling mengganti, dikatakan $B a^{\prime} a$ asy-syaia jika dia mengeluarkannya dari hak miliknya, dan $b a^{\prime} a h u$ jika dia membelinya dan memasukkannya ke dalam hak miliknya, dan ini masuk dalam kategori nama-nama yang memiliki lawan kata jika disebut ia mengandung makna dan lawannya seperti perkataan $a l-q u r^{\prime}$ yang berarti haid dan suci. Demikian juga dengan perkataan syara artinya mengambil dan syara yang berarti menjual. Allah berfirman: Dan mereka menjualnya dengan harga yang sedikit, artinya mereka menjual, karena masing-masing pihak telah mengambil ganti dan memberi ganti, yang satu sebagai penjual dengan yang ia beri dan pembeli dengan apa yang ia ambil, maka kedua nama ini layak untuk dijadikan sebagai sebutannya (Abdul Aziz Azzam, 2014, hlm. 23).

Dasar hukum jual beli dalam islam telah disampaikan pada QS. AlBaqarah (2): 275 dan QS. An-Nisa (4): 29 yang berbunyi :

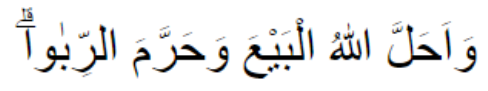

Artinya : "Allah telah menghalalkan jual beli dan mengharamkan riba..."(QS. Al-Baqarah (2): 275).

Penjelasan dari ayat tersebut bahwa Allah SWT telah mengatakan bahwa hukum dalam jual beli itu diperbolekan, dalam melakukan suatu transaksi yang dilarang oleh Allah SWT yaitu jual beli dengan unsur Riba di dalamnya

Adapun rukun jual beli menurut pendapat para jumhur ulama ada empat, yaitu:

2.1.1. Rukun Jual Beli
2.1.1.1. $B a^{\prime} i$ (penjual)
2.1.1.2. Mutari (pembeli)
2.1.1.3. Shigat (ijab dan qabul)
2.1.1.4. Ma'qud alaih (benda dan barang). (Rahmat Syafei, 2001, hlm. 75-76)

2.1.2. Syarat Jual Beli Dalam Islam

Suatu jual beli tidak sah bila tidak terpenuhi dalam suatu akad tujuh syarat, yaitu:

2.1.2.1. Saling rela antara kedua belah pihak.

2.1.2.2. Pihak-pihak pelaku akad, yaitu orang yang telah baligh, berakal, dan mengerti. Hal ini berdasarkan kepada firman Allah QS. an-nisa' (4): 5 


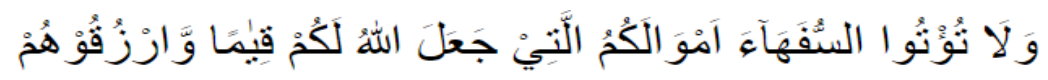

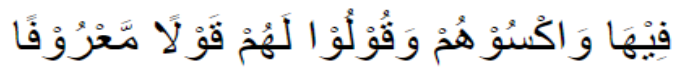

Artinya: "Dan janganlah kamu serahkan kepada orang yang belum sempurna akalnya, harta (mereka yang ada dalam kekuasaan) kamu yang dijadikan Allah sebagai pokok kehidupan. Berilah mereka belanja dan pakaian (dari hasil harta itu) dan ucakaplah kepada mereka perkataan yang baik" QS. an-nisaa' (4): 5

2.1.2.3. Harta yang menjadi objek transaksi telah dimiliki sebelumnya oleh kedua pihak. Maka, tidak sah jual beli barang yang belum dimiliki tanpa seizin pemiliknya. Hal ini berdasarkan Hadis Nabi SAW Riwayat Abu Daud dan Tirmidzi, sebagai berikut: "Janganlah engkau jual barang yang bukan milikmu."

2.1.2.4. Objek transaksi adalah barang yang dibolehkan agama. Maka tidak boleh menjual barang haram seperti khamar (minuman keras) dan lain-lain. Hal ini berdasarkan Hadis Nabi SAW Riwayat Ahmad: “Sesungguhnya Allah bila mengharamkan suatu barang juga mengharamkan nilai jual barang tersebut."

2.1.2.5. Objek transaksi adalah barang yang biasa diserah terimakan. Maka tidak sah jual mobil hilang, burung di angkasa karena tidak dapat diserahterimakan. Hal ini berdasarkan Hadis Nabi Riwayat Muslim: "Dari Abi Hurairah r.a. Bahwa Nabi Muhammad SAW melarang jual beli gharar (penipuan)."

2.1.2.6. Objek jual beli diketahui oleh kedua belah pihak saat akad. Maka tidak sah menjual barang yang tidak jelas. Misalnya, pembeli harus melihat terlebih dahulu barang tersebut dan/atau spesifikasi barang tersebut.

2.1.2.7. Harus jelas saat transaksi. Maka tidak sah jual beli di mana penjual mengatakan: "Aku jual mobil ini kepadamu dengan harga yang akan kita sepakati nantinya." (Mardani, 2015, hlm. 104-105).

\subsection{Salam}

Salam dapat didefinisikan sebagai transaksi atau akad jual beli di mana barang yang diperjual belikan belum ada ketika transaksi dilakukan, dan pembeli melakukan pembayaran di muka sedangkan penyerahan barang baru dilakukan di kemudian hari. PSAK 103 mendifinisikan Salam sebagai akad jual beli barang pesanan (muslam fiih) dengan pengiriman di kemudian hari oleh penjual (muslam ilaihi) dan pelaksanaannya dilakukan oleh pembeli (al muslam) pada saat akad 
disepakati sesuai dengan syarat-syarat tertentu (Sri Nurhayati Wasilah, 2008, hlm:180).

2.2.1 Rukun jual beli Salam

Pada umumnya, penjual meminta uang muka terlebih dahulu sebagai tanda pengikat dan sekaligus sebagai modal. Jual beli as-Salam juga dapat berlaku untuk mengimport barangbarang dari luar negeri dengan menyebutkan sifat-sifatnya, kualitas dan kuantitasnya. Penyerahan uang muka dan penyerahan barangnya dapat dibicarakan bersama dan biasanya dibuat dalam suatu perjanjian. Tujuan utama jual beli as-Salam ini adalah saling membantu dan mengutungkan kedua belah pihak. Transaksi Salam akan sah apabila memenuhi syarat dan rukunnya. Menurut (Ismail, 2011, hlm : 148) adapun rukun jual beli Salam adalah sebagai berikut:

2.2.1.1. Muslam yaitu dalam melakukan jual beli Salam harus ada pembeli.

2.2.1.2. Muslam ilaih yaitu dalam melakukan jual beli Salam harus ada penjual.

2.2.1.3. Orang yang berakad, baligh dan berakal

2.2.1.4. Barang yang dipesan harus jelas ciri-cirinya, waktunya, harganya

2.2.1.5. Ijab Qabul

2.2.2 Syarat-syarat dalam jual beli Salam

Menurut (Ismail, 2011, hlm : 148) adapun beberapa syaratsyarat dalam jual beli Salam adalah sebagai berikut:

2.2.2.1 Uangya hendaklah dibayar di tempat akad, berarti pembayaran dilakukan lebih dulu.

2.2.2.2 Barangnya menjadi utang bagi si penjual

2.2.2.3 Barangnya dapat diberikan sesuai waktu yang dijanjikan berarti pada waktu yang dijanjikan barang itu harus sudah ada.

2.2.2.4 Barang tersebut hendaklah jelas ukurannya, baik takaran, timbangan, ukuran, ataupun bilangannya, menurut kebiasaan cara menjual barang semacam itu.

2.2.2.5 Diketahui dan disebutkan sifat-sifat barangnya. Dengan sifat itu, berarti harga dan kemauan orang pada barang tersebut dapat berbeda. Sifat-sifat ini hendaknya jelas sehingga tidak ada keraguan yang akan mengakibatkan perselisihan nanti antara pembeli kedua belah pihak (si penjual dan si pembeli). Begitu juga macamnya, harus pula disebutkan, misalnya daging kambing, atau daging sapi.

2.2.2.6 Disebutkan tempat menerimanya, kalau tempat akad tidak layak buat menerima barang tersebut. Akad Salam meski terus, berarti tidak ada khiyar syara. 
2.2.2. Ketentuan - ketentuan Jual Beli Salam

Ketentuan - ketentuan Jual Beli Salam Menurut Fatwa

Dewan Syari'ah Nasional No : 05/DSN-MUI/IV/2000

2.2.2.1 Ketentuan tentang Pembayaran:

2.2.2.1.1 Alat bayar harus diketahui jumlah dan bentuknya, baik berupa uang, barang, atau manfaat.

2.2.2.1.2 Pembayaran harus dilakukan pada saat kontrak disepakati.

2.2.2.1.3 Pembayaran tidak boleh dalam bentuk pembebasan hutang.

2.2.2.2 Ketentuan tentang Barang:

2.2.2.2.1 Harus jelas ciri-cirinya dan dapat diakui sebagai hutang.

2.2.2.2.2 Harus dapat dijelaskan spesifikasinya.

2.2.2.2.3 Penyerahannya dilakukan kemudian.

2.2.2.2.4 Waktu dan tempat penyerahan barang harus ditetapkan berdasarkan kesepakatan.

2.2.2.2.5 Tidak boleh menukar barang, kecuali dengan barang sejenis sesuai kesepakatan.

2.2.2.3 Penyerahan Barang Sebelum atau pada Waktunya:

2.2.2.3.1 Penjual harus menyerahkan barang tepat pada waktunya dengan kualitas dan jumlah yang telah disepakati.

2.2.2.3.2 Jika penjual menyerahkan barang dengan kualitas yang lebih tinggi, penjual tidak boleh meminta tambahan harga.

2.2.2.3.3 Jika penjual menyerahkan barang dengan kualitas yang lebih rendah, dan pembeli rela menerimanya, maka ia tidak boleh menuntut pengurangan harga (diskon).

2.2.2.3.4 Penjual dapat menyerahkan barang lebih cepat dari waktu yang disepakati dengan syarat kualitas dan jumlah barang sesuai dengan kesepakatan, dan ia tidak boleh menuntut tambahan harga.

2.2.2.3.5 Jika semua atau sebagian barang tidak tersedia pada waktu penyerahan, atau kualitasnya lebih rendah dan pembeli tidak rela menerimanya, maka ia memiliki dua pilihan:

2.2.2.3.5.1 Membatalkan kontrak dan meminta kembali uangnya,

2.2.2.3.5.2 Menunggu sampai barang tersedia. 


\section{METODE PENELITIAN}

\subsection{Jenis Penelitian}

Penelitian ini menggunakan pendekatan kualitatif karena permasalahan yang dibahas dalam penelitian ini tidak berkenaan dengan angka-angka, tetapi mendiskripsikan, menguraikan, dan mengambarkan tentang implementasi sistem jual beli pre order menurut Fatwa Dewan Syari'ah Nasional No : 05/DSNMUI/IV/2000 tentang jual beli Salam pada pengusaha batik Asad di Kertijayan Pekalongan.

\subsection{Waktu dan tempat penelitian}

Penelitian ini dilaksanakan pada bulan Mei-Juni 2021. Lokasi yang digunakan untuk penelitian ini yaitu pengusaha atau pengrajin batik Asad Kertijayan, Pekalongan.

\subsection{Informan penelitian}

Adapun informan dari penelitian ini antara lain :

3.3.1. Informan kunci dalam penelitian ini yaitu tujuh karyawan yang bekerja dibagian unit pemasaran batik Asad Kertijayan Pekalongan, karena dianggap menguasai dan dekat dengan situasi yang menjadi fokus penelitian.

3.3.2. Informan pendukung dalam penelitian ini yaitu 23 pembeli atau pelanggan tetap dari batik Asad Kertijayan Pekalongan, penentuan jumlah informan pendukung ini didasari dari jumlah pelanggan tetap yang melakukan transaksi jual beli pre order (Salam) di batik Asad Kertijayan Pekalongan yaitu sebanyak 23 pelanggan tetap, sehingga peneliti mengambil seluruh pelanggan tetap berjumlah 23.

\subsection{Teknik pengumpulan data}

Teknik pengumpulan data merupakan langkah yang paling utama dalam penelitian, karena tujuan utama dari penelitian adalah mendapatkan data. Untuk mendapatkan kelengkapan informasi atau data yang sesuai dengan fokus penelitian maka metode pengumpulan data yang digunakan yaitu

3.4.1. Metode Observasi

Metode observasi merupakan suatu penelitian yang dilakukan dengan cara mengadakan pengamatan terhadap objek baik secara langsung maupun tidak langsung, karena dengan menggunakan pengamatan memungkinkan gejalagejala penelitian dapat diamati dari dekat (Marzuki, 1989:72)

3.4.2. Metode Wawancara (Interview)

Metode wawancara (Interview) adalah suatu metode penelitian yang dilakukan untuk mendapatkan jawaban dari informan dengan jalan tanya jawab, atau interview adalah dialog yang dilakukan oleh pewawancara untuk memperoleh informasi dari wawancara (Ali, Muhammad, 1992:144). 


\subsubsection{Metode Snowbolling}

Penentuan informan kunci dan pendukung tersebut menggunakan metode snowballing. Metode Snowbolling adalah teknik pengambilan sumber data yang pada awalnya jumlahnya sedikit tersebut belum mampu memberikan data yang lengkap, maka harus mencari informan lain yang dapat digunakan sebagai sumber data. Sugiyono (2008; hlm 300)

\subsection{Teknik analisis data}

Untuk melaksanakan analisis data kualitatif ini maka perlu ditekankan beberapa tahapan dan langkah-langkah yaitu

\subsubsection{Reduksi Data}

Reduksi data diartikan sebagai proses pemilihan, pemusatan perhatian dan penyederhanaan, pengabstrakan dan transformasi data kasar yang muncul dari catatan-catatan tertulis dilapangan. Mereduksi data bisa berarti merangkum, memilah hal-hal yang pokok, memfokuskan pada hal-hal yang penting, dicari tema dan polanya (Sugiyono, 2009, hlm: 92).

\subsubsection{Penyajian Data}

Penyajian data adalah kegiatan ketika sekumpulan informasi disusun, sehingga memberi kemungkinan akan adanya penarikan kesimpulan (Ariesto Hadi Sutopo dan Adrianus Arief, 2010). Penyajian data dilakukan dengan tujuan mempermudah peneliti dalam melihat gambaran secara keseluruhan atau bagian tertentu dari penelitian.

\subsubsection{Penarikan kesimpulan}

Penarikan kesimpulan yaitu melakukan verifikasi secara terus-menerus sepanjang proses penelitian berlangsung, yaitu selama proses pengumpulan data. Peneliti berusaha untuk menganalisis data dan mencari pola, tema, hubungan persamaan, hal-hal yang sering timbul, hipotesis dan sebagainya yang dituangkan dalam kesimpulan yang tentatif. Penelitian ini, penarikan kesimpulan dilakukan dengan pengambilan intisari dari rangkaian kategori hasil penelitian berdasarkan observasi serta wawancara yang dilakukan oleh peneliti.

\section{HASIL DAN PEMBAHASAN}

Berdasarkan hasil survei yang telah dilakukan oleh peneliti, dengan dilakukannya wawancara antara produsen karyawan, dan pembeli Batik Asad Kertijayan Pekalongan. Peneliti akan menguraikan beberapa data dari lapangan sebagai bahan pertimbangan, apakah sudah sesuai pelaksanaan sistem jual beli Salam (pre order) di batik Asad dengan ketentuan Fatwa DSN-MUI No 05/DSN-MUI/IV/2000 yang benar. Dalam hal ini peneliti melakukan wawancara langsung terhadap 30 informan 
diantaranya yaitu 4 admin pemasaran, 3 karyawan produksi dan 23 pembeli tetap dari Batik Asad Kertijayan Pekalongan.

4.1. Berkaitan dengan rukun dan syarat jual beli Salam dalam ekonomi islam

4.1.1. Rukun jual beli Salam dalam ekonomi islam :

4.1.1.1. Muslam yaitu dalam melakukan jual beli Salam harus ada pembeli.

4.1.1.2. Muslam ilaih yaitu dalam melakukan jual beli Salam harus ada penjual.

4.1.1.3. Orang yang berakad, baligh dan berakal

4.1.1.4. Barang yang dipesan harus jelas ciri-cirinya, waktunya, harganya

\subsubsection{Ijab Qabul}

Pelaksanaan pada Batik Asad Kertijayan Pekalongan berkaitan dengan rukun jual beli Salam terdapat adanya pembeli (pelanggan batik Asad Kertijayan Pekalongan) dan terdapat penjual (produsen atau pemilik dari Batik Asad Kertijayan Pekalongan). Antara pembeli dan penjual pada Batik Asad ini melakukan suatu akad jual beli pesanan yang disebut pre order (Salam), dan pembeli maupun penjual dari batik Asad ini tentunya baligh dan berakal. Barang yang diperjualkan yaitu pakaian batik dalam pelaksanaan transaksinya dijelaskan tentang ciri-ciri, spesifikasi, dan harganya. Kemudian terdapat kesepakatan atau ijab qabul dalam transaksi sistem jual beli pre order yang dilakukan oleh pembeli dan penjual.

4.1.2. Syarat jual beli Salam dalam ekonomi islam :

4.1.2.1. Uangya hendaklah dibayar di tempat akad.

4.1.2.2. Barangnya menjadi utang bagi si penjual

4.1.2.3. Barangnya dapat diberikan sesuai waktu yang dijanjikan

4.1.2.4. Barang tersebut hendaklah jelas ukurannya, baik takaran, timbangan, ukuran, ataupun bilangannya, menurut kebiasaan cara menjual barang semacam itu.

4.1.2.5. Diketahui dan disebutkan sifat-sifat barangnya. Dengan sifat itu, berarti harga dan kemauan orang pada barang tersebut dapat berbeda. Sifat-sifat ini hendaknya jelas sehingga tidak ada keraguan yang akan mengakibatkan perselisihan nanti antara pembeli kedua belah pihak (si penjual dan si pembeli). Begitu juga macamnya, harus pula disebutkan, misalnya daging kambing, atau daging sapi.

4.1.2.6. Disebutkan tempat menerimanya 
Pelaksanaan pada Batik Asad kertijayan Pekalongan terkait dengan syarat jual beli Salam yaitu pembeli melakukan pembayaran secara tunai atau dimuka kepada penjual. Kemudian setelah pembeli melakukan pembayaran maka itu menjadi utang bagi si penjual terkait dengan pakaian batik yang dipesan oleh pembeli. Pakaian batik yang telah selesai di produksi, maka penjual akan memberikan konfirmasi kepada pembeli sesuai dengan waktu yang telah ditentukan. Pakaian batik yang di tawarkan atau dijual sebelumnya dijelaskan secara detail tentang ukuran, warna, jumlah yang akan dipesan, dan harganya. Dijelaskan pula tentang sifat-sifat dari pakaian batik yang diperjualkan seperti pakaian batik daster, longdress, setelan kulot, kulot jumbo, celana panjang, celana panjang jumbo, atasan, dan setelan anak. Pelaksanaan pada batik Asad terkait dengan tempat penyerahan atau tempat penerimaan nya, pembeli dan penjual akan melakukan kesepakatan dimana pakaian batik yang dipesan oleh pembeli akan di serahkan atau diterima.

4.2. Ketentuan tentang Pembayaran:

Ketentuan umum tentang pembayaran Salam diatur dalam Fatwa DSN-MUI No 05/DSN-MUI/IV/2000 :

4.2.1. Alat bayar harus diketahui jumlah dan bentuknya, baik berupa uang, barang, atau manfaat.

4.2.2. Pembayaran harus dilakukan pada saat kontrak disepakati.

4.2.3. Pembayaran tidak boleh dalam bentuk pembebasan hutang. Pelaksanaan Pada Batik Asad Kertijayan Pekalongan alat bayar yang digunakan adalah berbentuk uang. Uang yang dibayarkan oleh konsumen batik Asad yaitu diawal atau dimuka sebelum pembuatan pesanan. Jumlah yang dibayarkanpun sesuai dengan jumlah pesanan yang dipesan oleh konsumen kepada pengusaha Batik Asad. Pelaksanaan pembayaran yang dilakukan antara pembeli dan penjual yaitu pada saat akad jula beli diantara kedua belah pihak, sesuai dengan kesepakatan penjual dan pembeli. Sistem pembayaran yang dilakukan oleh pembeli bukan lah untuk pembebasan hutang melainkan untuk bentuk kesepakatan sebuah pesanan barang yang telah dipesan oleh pembeli kepada penjual.

4.3. Ketentuan tentang Barang:

Dalam fatwa DSN-MUI No 05/DSN-MUI/IV/2000 berkaitan dengan ketentuan tentang barang yaitu :

4.3.1. Harus jelas ciri-cirinya dan dapat diakui sebagai hutang.

4.3.2. Harus dapat dijelaskan spesifikasinya

4.3.3. Penyerahannya dilakukan kemudian 
4.3.4. Waktu dan tempat penyerahan barang harus ditetapkan berdasarkan kesepakatan,

4.3.5. Tidak boleh menukar barang, kecuali dengan barang sejenis sesuai kesepakatan.

Pelaksanaan pada Batik Asad Kertijayan Pekalongan pengusaha sebagai pihak penjual atau admin selaku karyawan pemasaran apabila terdapat pembeli yang akan memesan batik, maka admin akan menjelaskan secara detail ciri-ciri dari batik atau barang yang akan dipesan oleh pembeli. Berkenaan dengan produk batik yang dijelaskan ciri-cirinya tersebut belum terdapat stoknya, maka ini diakui sebagai bentuk hutang penjual terhadap pembeli yang berkaitan dengan ciri-ciri batik tersebut. Pada Batik Asad Kertijayan Pekalongan admin pemasaran atau pengusaha akan menjelaskan spesifikasi dari batik yang dipesan oleh pembeli baik itu dari segi ukuran, warna, model, dan harga. Penyerahan batik yang dipesan oleh pembeli dilakukan setelah batik itu selesai di kerjakan oleh karyawan produksi dari Batik Asad Kertijayan Pekalongan dan setelah pengerjaan pesanan batik selesai maka akan dipacking dan diserahkan kepada pembeli. Pada Batik Asad Kertijayan Pekalongan admin akan menetapkan waktu dan tempat penyerahan batik berdasarkan kesepakatan antara penjual dan pembeli. Pelaksanaan Pada Batik Asad Kertijayan Pekalongan dalam transaksi jual beli Salam (pre order) pembeli tidak diperbolehkan menukarkan batik yang telah dipesan nya dengan pakaian batik lain, kecuali ada perubahan warna, ukuran, jumlah, dari pembeli sebelum batik tersebut diproduksi maka perubahan tersebut bisa diterima atau diperbolehkan dalam pelaksanaan transaksi jual beli pada batik Asad Kertijayan Pekalongan.

4.4. Penyerahan Barang Sebelum atau pada Waktunya:

Dalam fatwa DSN-MUI No 05/DSN-MUI/IV/2000 berkaitan dengan ketentuan tentang penyerahan barang sebelum atau pada waktunya yaitu :

4.4.1. Penjual harus menyerahkan barang tepat pada waktunya dengan kualitas dan jumlah yang telah disepakati.

4.4.2. Jika penjual menyerahkan barang dengan kualitas yang lebih tinggi, penjual tidak boleh meminta tambahan harga.

4.4.3. Jika penjual menyerahkan barang dengan kualitas yang lebih rendah, dan pembeli rela menerimanya, maka ia tidak boleh menuntut pengurangan harga (diskon).

4.4.4. Penjual dapat menyerahkan barang lebih cepat dari waktu yang disepakati dengan syarat kualitas dan jumlah barang sesuai dengan kesepakatan, dan ia tidak boleh menuntut tambahan harga. 
4.4.5. Jika semua atau sebagian barang tidak tersedia pada waktu penyerahan, atau kualitasnya lebih rendah dan pembeli tidak rela menerimanya, maka ia memiliki dua pilihan:

4.4.5.1. Membatalkan kontrak dan meminta kembali uangnya,

4.4.5.2. Menunggu sampai barang tersedia.

Pelaksanaan pada Batik Asad Kertijayan Pekalongan penjual menyerahkan barang tepat pada waktunya sesuai kesepakatan pada saat akad dengan kriteria dan spesifikasi pesanan yang telah ditentukan pembeli kepada penjual. Kualitas batik yang dipesan oleh pembeli menjadi tanggung jawab penjual, apabila batik yang dipesan pembeli mengalami kerusakan atau permasalahan lainya yang disebabkan oleh pihak Batik Asad maka pihak dari Batik Asad akan mengganti dan memperbaiki pesanan dari pembeli tanpa adanya penambahan harga. Dalam pelaksanaan sistem jual beli pre order (Salam) Batik Asad Kertijayan Pekalongan, jika semua atau sebagian barang tidak tersedia pada waktu penyerahan, atau kualitasnya lebih rendah dan pembeli tidak rela menerimanya, yang dilakukan oleh pihak Batik Asad adalah melakukan kesepakatan dengan pembeli tanpa adanya unsur paksaan yaitu dengan membatalkan kontrak dan mengembalikan uang pembeli atau pembeli dapat menunggu sampai barang tersedia kembali.

Tabel 4.1

Jual Beli Salam Perspektif Fatwa dan Jual Beli Pre Order (Salam) Pada Batik Asad Kertijayan Pekalongan

\begin{tabular}{|c|c|c|}
\hline & $\begin{array}{l}\text { FATWA DSN-MUI NO 05/DSN- } \\
\text { MUI/IV/2000 TENTANG JUAL } \\
\text { BELI SALAM }\end{array}$ & $\begin{array}{l}\text { JUAL BELI PRE } \text { ORDER } \\
(S A L A M) \text { PADA BATIK ASAD } \\
\text { KERTIJAYAN PEKALONGAN }\end{array}$ \\
\hline $\begin{array}{l}\text { Rukun dan } \\
\text { syarat jual beli } \\
\text { Salam dalam } \\
\text { ekonomi } \\
\text { islam }\end{array}$ & $\begin{array}{l}\text { Rukun jual beli Salam dalam } \\
\text { ekonomi islam : } \\
\text { a. } \\
\text { Muslam yaitu dalam } \\
\text { melakukan jual beli Salam } \\
\text { harus ada pembeli. } \\
\text { b. } \\
\text { Muslam ilaih yaitu dalam } \\
\text { melakukan jual beli Salam } \\
\text { harus ada penjual. } \\
\text { c. } \text { Orang yang berakad, baligh } \\
\text { dan berakal } \\
\text { d. } \text { Barang yang dipesan harus } \\
\text { jelas ciri-cirinya, waktunya, } \\
\text { harganya } \\
\text { e. }\end{array}$ & $\begin{array}{l}\text { Pelaksanaan pada Batik } \\
\text { Asad Kertijayan } \\
\text { Pekalongan berkaitan } \\
\text { dengan rukun jual beli } \\
\text { Salam terdapat adanya } \\
\text { pembeli (pelanggan batik } \\
\text { Asad Kertijayan } \\
\text { Pekalongan) dan terdapat } \\
\text { penjual (produsen atau } \\
\text { pemilik dari Batik Asad } \\
\text { Kertijayan Pekalongan). } \\
\text { Antara pembeli dan penjual } \\
\text { pada Batik Asad ini } \\
\text { melakukan suatu akad jual } \\
\text { beli pesanan yang disebut } \\
\text { pre order (Salam), dan } \\
\text { pembeli maupun penjual }\end{array}$ \\
\hline
\end{tabular}




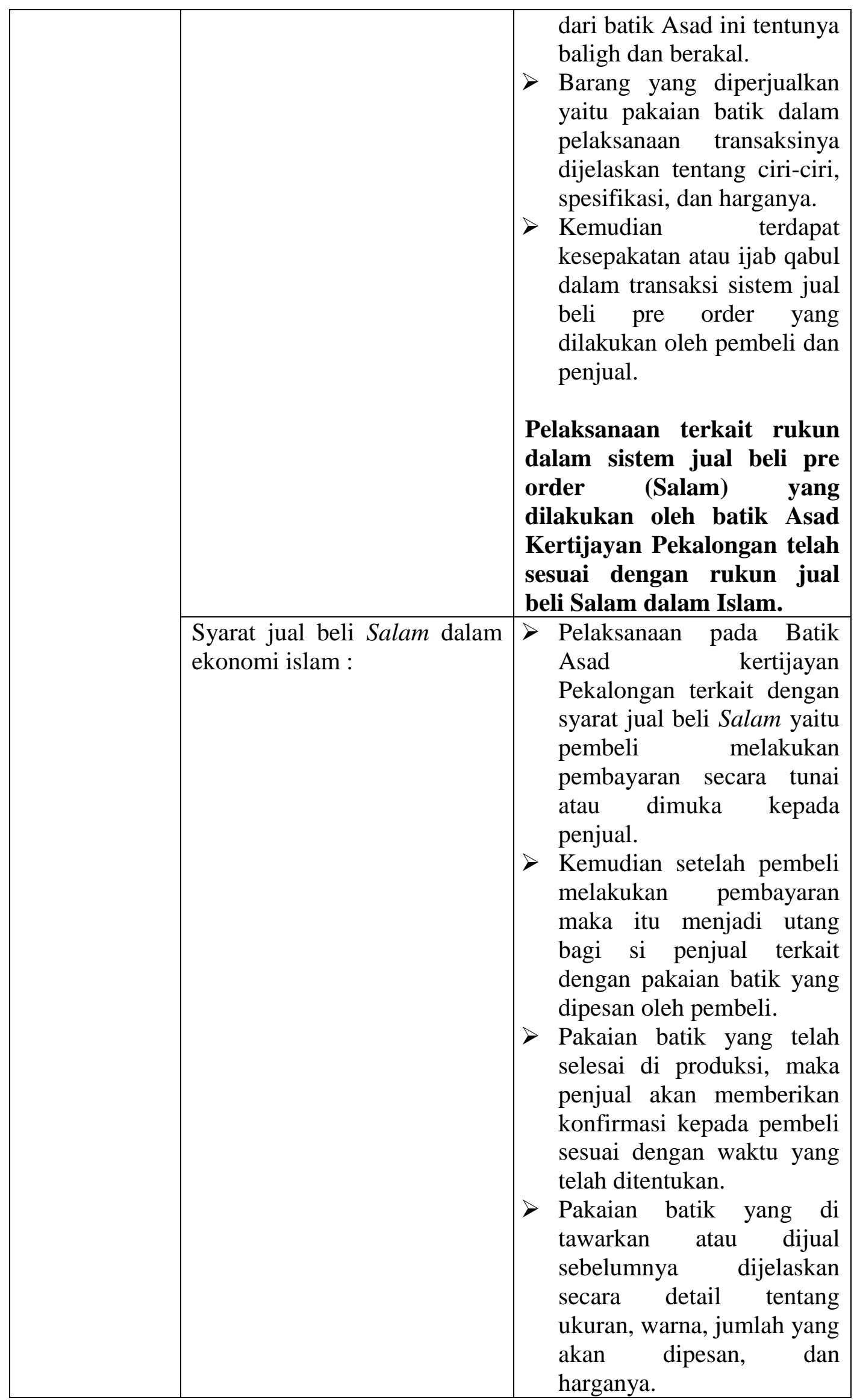




\begin{tabular}{|c|c|c|}
\hline & & 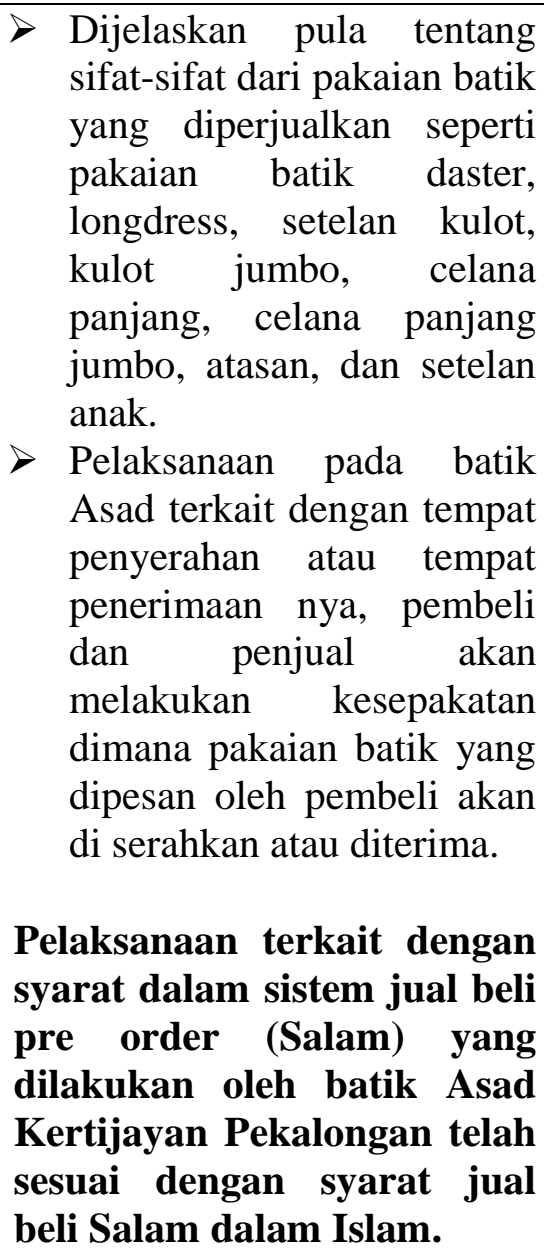 \\
\hline $\begin{array}{l}\text { Ketentuan } \\
\text { tentang } \\
\text { Pembayaran }\end{array}$ & 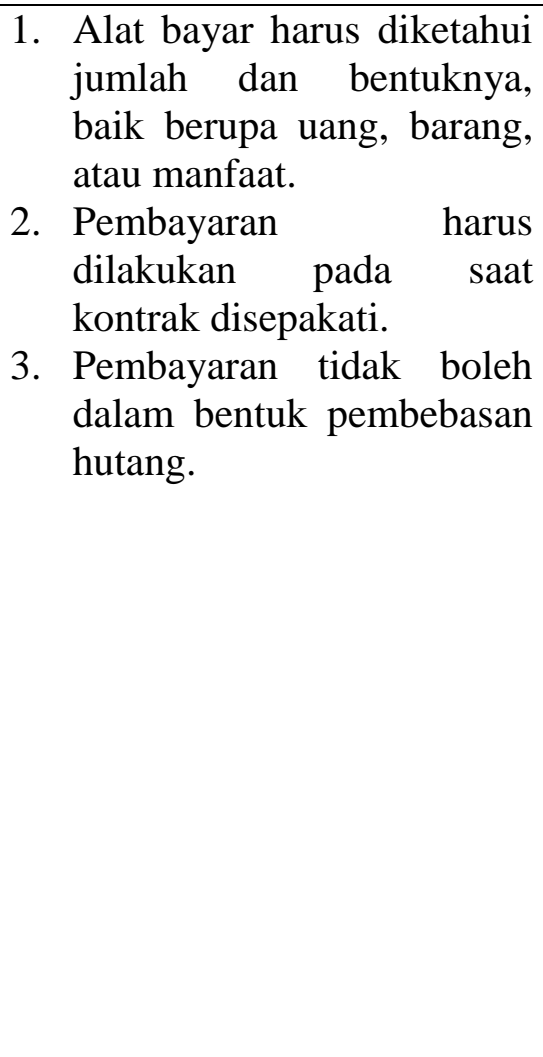 & $\begin{array}{l}\checkmark \text { Pelaksanaan Pada Batik } \\
\text { Asad Kertijayan } \\
\text { Pekalongan alat bayar yang } \\
\text { digunakan adalah } \\
\text { berbentuk uang. Uang yang } \\
\text { dibayarkan oleh konsumen } \\
\text { batik Asad yaitu diawal } \\
\text { atau dimuka sebelum } \\
\text { pembuatan pesanan. } \\
\checkmark \text { Jumlah yang } \\
\text { dibayarkanpun sesuai } \\
\text { dengan jumlah pesanan } \\
\text { yang dipesan oleh } \\
\text { konsumen kepada } \\
\text { pengusaha Batik Asad. } \\
\text { Pelaksanaan pembayaran } \\
\text { yang dilakukan antara } \\
\text { pembeli dan penjual yaitu } \\
\text { pada saat akad jula beli } \\
\text { diantara kedua belah pihak, } \\
\text { sesuai dengan kesepakatan } \\
\text { penjual dan pembeli. }\end{array}$ \\
\hline
\end{tabular}




\begin{tabular}{|c|c|c|}
\hline & & $\begin{array}{lr}\checkmark & \text { Sistem pembayaran yang } \\
\text { dilakukan oleh pembeli } \\
\text { bukan lah } & \text { untuk } \\
\text { pembebasan } & \text { hutang } \\
\text { melainkan untuk } & \text { bentuk } \\
\text { kesepakatan } & \text { sebuah } \\
\text { pesanan barang yang telah } \\
\text { dipesan oleh pembeli } \\
\text { kepada penjual. } \\
\text { Pelaksanaan terkait dengan } \\
\text { pembayaran dalam sistem } \\
\text { jual beli pre order (Salam) } \\
\text { yang dilakukan oleh batik } \\
\text { Asad Kertijayan Pekalongan } \\
\text { telah sesuai dengan } \\
\text { ketentuan tantang } \\
\text { pembayaran pada fatwa } \\
\text { DSN MUI NO 05/IV/2000 } \\
\text { Tentang jual beli Salam }\end{array}$ \\
\hline $\begin{array}{l}\text { Ketentuan } \\
\text { tentang } \\
\text { Barang }\end{array}$ & $\begin{array}{l}\text { 1. Harus jelas ciri-cirinya } \\
\text { dan dapat diakui sebagai } \\
\text { hutang. } \\
\text { 2. Harus dapat dijelaskan } \\
\text { spesifikasinya } \\
\text { 3. Penyerahannya dilakukan } \\
\text { kemudian } \\
\text { 4. Waktu dan tempat } \\
\text { penyerahan barang harus } \\
\text { ditetapkan berdasarkan } \\
\text { kesepakatan, } \\
\text { 5. Pembeli tidak boleh } \\
\text { menjual barang sebelum } \\
\text { menerimanya, } \\
\text { 6. Tidak boleh menukar } \\
\text { barang, kecuali dengan } \\
\text { barang sejenis sesuai } \\
\text { kesepakatan. }\end{array}$ & $\begin{array}{l}\text { Pelaksanaan pada Batik } \\
\text { Asad Kertijayan } \\
\text { Pekalongan pengusaha } \\
\text { sebagai pihak penjual atau } \\
\text { admin selaku karyawan } \\
\text { pemasaran apabila terdapat } \\
\text { pembeli yang akan } \\
\text { memesan batik, maka } \\
\text { admin akan menjelaskan } \\
\text { secara detail ciri-ciri dari } \\
\text { batik atau barang yang } \\
\text { akan dipesan oleh pembeli. } \\
\text { Berkenaan dengan produk } \\
\text { batik yang dijelaskan ciri- } \\
\text { cirinya tersebut belum } \\
\text { terdapat stoknya, maka ini } \\
\text { diakui sebagai bentuk } \\
\text { hutang penjual terhadap } \\
\text { pembeli yang berkaitan } \\
\text { dengan ciri-ciri batik } \\
\text { tersebut. } \\
\text { Pada Batik Asad Kertijayan } \\
\text { Pekalongan admin } \\
\text { pemasaran atau pengusaha } \\
\text { akan menjelaskan } \\
\text { spesifikasi dari batik yang } \\
\text { dipesan oleh pembeli baik }\end{array}$ \\
\hline
\end{tabular}




\begin{tabular}{|c|c|c|}
\hline & & 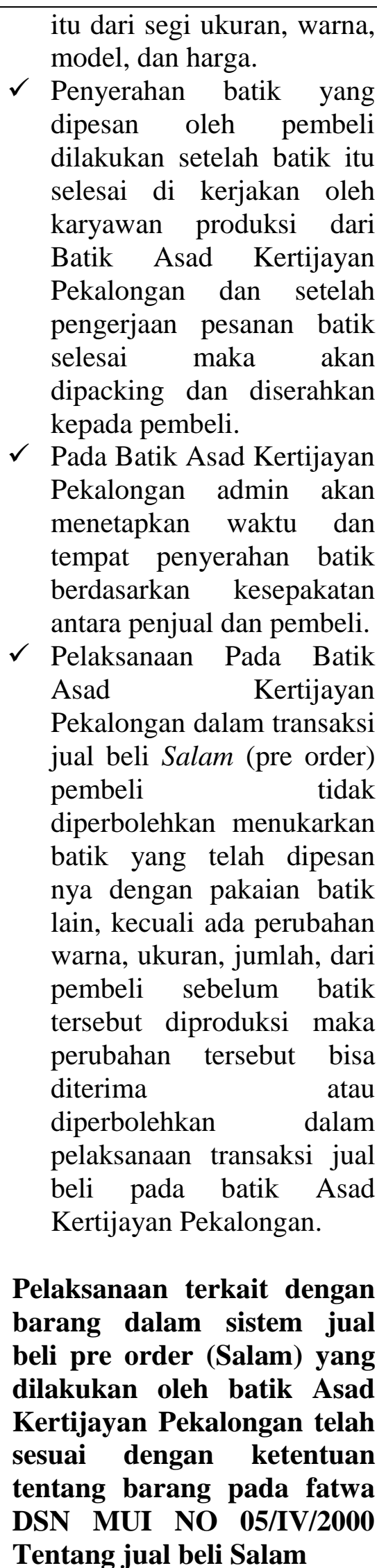 \\
\hline Penyerahan & 1. Penjual harus & $\checkmark$ Pelaksanaan pada Batik \\
\hline
\end{tabular}




\begin{tabular}{|c|c|c|}
\hline $\begin{array}{l}\text { Barang } \\
\text { Sebelum atau } \\
\text { pada } \\
\text { Waktunya }\end{array}$ & 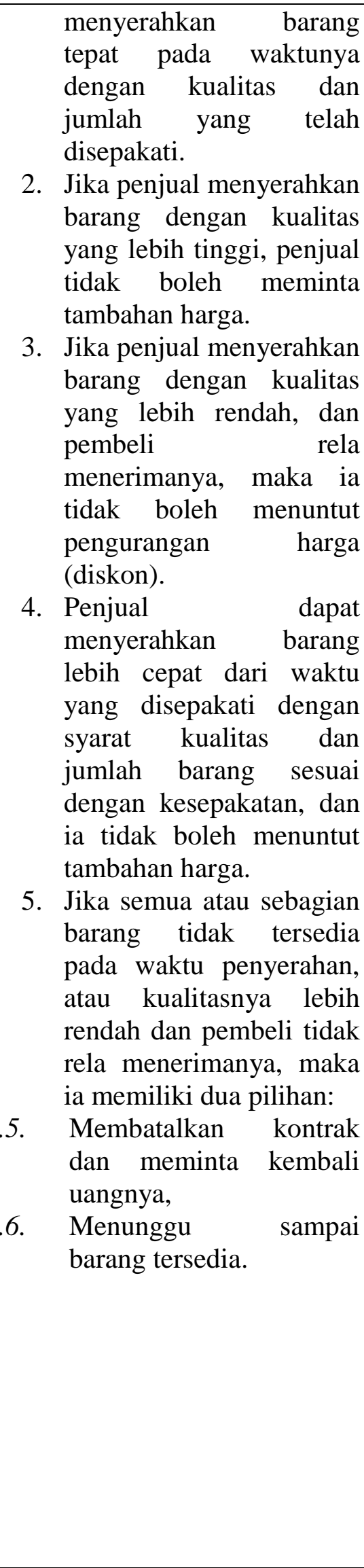 & 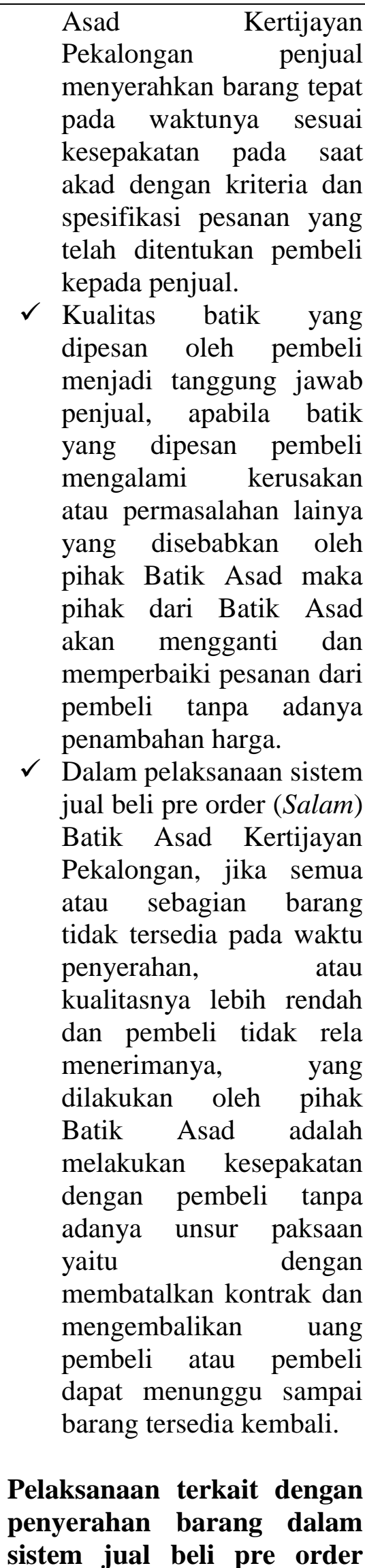 \\
\hline
\end{tabular}




\begin{tabular}{|l|l|l|}
\hline & (Salam) yang dilakukan oleh \\
batik Asad Kertijayan \\
Pekalongan telah sesuai \\
dengan ketentuan tentang \\
penyerahan barang pada \\
fatwa DSN MUI NO \\
05/IV/2000 Tentang jual beli \\
Salam.
\end{tabular}

\section{KESIMPULAN DAN SARAN}

\subsection{Kesimpulan}

Berdasarkan hasil penelitian, tentang pelaksanaan jual beli Salam (Pre order) pada Batik Asad Kertijayan Pekalongan dalam memahami implementasi FATWA DSN-MUI NO 05/DSNMUI/IV/2000 Tentang Jual Beli Salam, maka kesimpulan yang dapat diambil sesuai dengan rumusan masalah, yaitu :

5.1.1. Pelaksanaan sistem jual beli pre order (Salam) pada batik Asad Kertijayan Pekalongan yaitu pembeli memesan batik kepada batik Asad. Dalam sistem pembayaran pembeli membayarkan sepenuhnya jumlah uang yang telah ditentukan sebagai tanda jadi akad sesuai dengan barang yang dipesannyadan penjual (batik Asad) akan menjelaskan tentang spesifikasi barang yang akan dipesan, jenis barang, waktu pengiriman, dan tempat penyerahannya.

5.1.2. Pelaksanaan sistem jual beli pre order (Salam) pada batik Asad Kertijayan Pekalongan terkait ketentuan tentang pembayaran yaitu telah sesuai dengan FATWA DSN-MUI NO 05/DSN-MUI/IV/2000 Tentang Jual Beli Salam

5.1.3. Pelaksanaan sistem jual beli pre order (Salam) pada batik Asad Kertijayan Pekalongan terkait ketentuan tentang barang yaitu telah sesuai dengan FATWA DSN-MUI NO 05/DSN-MUI/IV/2000 Tentang Jual Beli Salam

5.1.4. Pelaksanaan sistem jual beli pre order (Salam) pada batik Asad Kertijayan Pekalongan terkait ketentuan tentang penyerahan barang yaitu telah sesuai dengan FATWA DSNMUI NO 05/DSN-MUI/IV/2000 Tentang Jual Beli Salam

5.1.5. Pelaksanaan jual beli Salam (Pre order) pada Batik Asad Kertijayan Pekalongan telah memenuhi rukun dan syarat jual beli Salam menurut ekonomi islam.

\subsection{Saran}

Berdasarkan penelitian yang telah dijalankan ada beberapa saran yang dapat diajukan, sebagai berikut :

5.2.1. Dalam penelitian selanjutnya, disarankan untuk objek penelitian tidak hanya difokuskan pada satu objek atau satu pengusaha batik yang melakukan jual beli Pre order (Salam). 
5.2.2. Dengan mengetahui ketentuan-ketentuan yang di tetapkan oleh FATWA DSN-MUI NO 05/DSN-MUI/IV/2000 Tentang Jual Beli Salam diharapkan agar kita lebih bijak dalam melakukan praktik bermuamalah sehingganya mendapatkan barokah dari bermuamalah itu sendiri. Terlebih dalam hal menjual kembali barang yang belum diterima dalam akad Salam, lebih baik di terima dahulu sehingganya dapat di perjual belikan secara bebas tanpa mengurangi baik dan buruknya jual beli itu sendiri.

\subsection{Keterbatasan}

Berdasarkan pada pengalaman langsung penulis dalam penelitian ini, ada keterbatasan yang dialami dan dapat menjadi faktor yang dapat diperhatikan bagi peneliti-peneliti yang akan datang dalam lebih menyempurnakan penelitiannya, karena penelitian ini tentu memiliki kekurangan yang perlu terus diperbaiki dalam penelitian-penelitian kedepannya. Keterbatasan dalam penelitian ini yaitu objek penelitian hanya difokuskan pada satu pengusaha batik yang melakukan jual beli Pre order (Salam).

\section{DAFTAR PUSTAKA}

Al hadi, A. A. (2017). Fikih Muamalah Kontemporer. Depok: Raja Grafindo Persada.

Al Jazily, A. R. (2006). Al-Figh 'Ala Al-Madzahib al-'Arba'ah. Bayrut: Dar al-Kita alIlmiyah.

Antonio, M. S. (2001). Bank Syariah: Dari Teori Ke Prakti. Jakarta: Gema Insani Press.

Antonio, M. S. (2007). Bank syari'ah dari teori ke praktik. Jakarta: Gema Insani.

Anugra, R. P. (2018). Implementasi khiyar dalam jual beli sistem preorder dalam perspektif ekonomi islam. Makassar: Uin Alauddin Makassar. Makassar: Uin Alaudin Makassar.

Ascarya. (2009). Akad dan Produk Bank Syari'ah. Jakarta: Raja Grafindo Persada.

Azzam, A. A. (2014). Fiqih Muamalah. Jakarta: Amzah.

Desmiharti, I. (2019). Hukum Transaksi Jual Beli dengan Sistem Pre-Order dalam Pandangan Islam. Riau: Universitas Muhammadiyah Riau.

Djuwaini, D. (2015). Pengantar Fiqh Muamalah. Yogyakarta: Pustaka Pelajar.

Fathoni, A. (2011). Metodologi Penelitian dan Teknik Penyusunan Skripsi. Jakarta: PT. Rineka Cipta.

Hasan, M. A. (2004). Berbagai Macam Transaksi Dalam Islam. Jakarta: Raja Grafindo.

Hasan, M. A. (2004). Berbagai Macam Transaksi Dalam Islam. Jakarta: RajaGrafindo Persada.

Hidayat, E. (2015). Fiqh Jual Beli. Bandung: Remaja Rosdakarya.

Ismail. (2011). Perbankan Syariah. Jakarta: Kencana.

Jafri, a. s. (2008). Fiqh Muamalah. Riau: Suska Press.

Khallaf, A. W. (1994). Kaidah-kaidah Hukum Islam. Jakarta: Raja Grafindo Persada.

L. A. (2012). Jual Beli dengan Sistem Al-Bai"u Salam dalam Pembiayaan Syariah di Indonesia. Jember: Universitas Jember Fakultas Hukum.

Mardini. (2015). Fiqh Ekonomi Syariah Fiqh Muamalah. Jakarta: Prenadamedia group. Martha, \& Kresno. (2016). Metodologi Penelitian Kualitatif. Jakarta: Rajawali Press. 
Ma'ruf, F. (2016). Perlindungan Hukum Terhadap Konsumen Dalam Perjanjian Jual Beli Hijab dengan Sistem Pre Order Antara Toko Hijab AH dengan Konsumen di Kota Yogyakarta"dalam Repository. Yogyakarta: Universitas Gaja Mada.

Minhajuddin. (2011). Hikmah dan Filsafat Fikih Muamalah dalam Islam. Makasar: Alaudin University Press.

Moelong, L. J. (1999). Metodologi penelitian kualitatif, . Bandung: PT. Remaja Rosdakarya.

Mubarak, J. (2017). Fikih Mua"malah Maliyyah Akad Jual Beli. Bandung: Simbiosa Rekatama Media.

Mubarak, J., \& Hasanuddin. (2017). Fikih Mua"malah Maliyyah Akad Jual Beli. Bandung: Simbiosa Rekatama Media.

Mustofa, I. (2014). Fiqih Muamalah Kontempore. Yogyakarta: STAIN Jusi Metro Lampung.

Mustofa, I. (2016). Fiqh Muamalah Kontemporer. Jakarta: Rajawali Pers.

Nasution. (2012). Metode Research (Penelitian Ilmiah). Jakarta: Bumi Aksara.

Nawawi, I. (2012). Fikih Muamalah Klasik dan Kontemporer. Bogor: Ghalia Indonesia.

Nawawi, I. (2012). Fikih Muamalah Klasik dan Kontemporer. Surabaya: Ghalia.

Ntonio, M. S. (2007). Bank Syari'ah dari Teori ke Praktik. Jakarta: Gema Insani.

Nurainun, Heriyana, \& Rasyimah. (2008). Analisis Industri Batik Di Indonesia. Fokus Ekonomi (FE), 124.

Qusthoniah. (2016). Analisis Kritis Akad Salam di Perbankan Syariah. Syari"ah, 88.

R, N. F. (2015). Efektivitas Penggunaan Alat Bantu Reaksi Gerakan Tangan Bagi Kaum Disabilitas. Jakarta: Universitas Pendidikan Indonesia. Jakarta: Universitas Pendidikan Indonesia.

Rivai, V. (2012). Islamic Marketing. Jakarta: Gramedia Pustaka Utama.

Saleh, H. (2008). Kajian Fiqh Nabawi dan Fiqh Kontemporer. Jakarta: Raja Grafindo Persada.

Santoso, S. (2016). Sistem Transaksi E-Commerce dalam Perspektif KUH Perdata Dan Hukum Islam. AHKAM, 218-219.

Sugiyono. (2008). Metode Penelitian Kuantitatif Kualitatif dan R\&D. Bandung: Alfabeta.

Sugiyono. (2009). Memahami Penelitian Kualitatif. Bandung: Alfabeta.

Suhendi, H. (2005). Fiqh Muamalah. Jakarta: RajaGrafindo Persada.

Sutopo, A. H., \& Arief, A. (2010). Terampil Mengolah Data Kualitatif dengan NVIVO. Jakarta: Prenada Media Group.

Syafei, R. (2001). Fiqh Muamalah. Bandung: Pustaka Setia.

syaikhu, Ariyadi, \& Norwili. (2020). Fikih Muamalah Memahami Konsep dan Dialektika Kontemporer. Yogyakarta: K Media.

Wasilah, S. N. (2008). Akuntansi Syari'ah di Indonesia. Jakarta: Salemba Empat.

Yusuf, M. (n.d.). Metode Penelitian: Kuantitatif, Kualitatif, dan Penelitian Gabungan, 384.

Zuhaili, W., \& Utomo, S. B. (1999). Fiqh Muamalah Perbankan Syari"ah. Jakarta: PT. Bank Muamalat Indonesia, TBK.

Zulkifli, S. (2003). Panduan Praktis Transaksi Perbankan Syari'ah. Jakarta: Zikrul Hakim. 